\title{
The Coaching of Football Extracurricular
}

\author{
$\operatorname{Argantos}^{1^{*}}$ and Gilang Cahyadi ${ }^{2}$ \\ 1,2Dep. of Coaching, Faculty of Sport Science, Universitas Negeri Padang, Padang, Indonesia \\ *Corresponding author. Email: argantos@fik.unp.ac.id
}

\begin{abstract}
The problem in this study is that coaching is not going well and decreasing the extracurricular football achievements of Semen Padang High School. One of the efforts to increase the achievements of Seman Padang High School in producing high-achieving students is by conducting a quality and appropriate coaching process conducted by people who have potential in their fields. The research method is qualitative research. Data collection methods used were observation, interview, and documentation. Informants in this study include the teacher's supervisor, trainer, and student participants. Mechanical analysis of the data used is analysis techniques Ku agitation which includes three concurrent activities namely data reduction, data presentation and draw conclusions. Based on the results of research and language, it can be concluded : (1) Coaching given to the participants is still not running in accordance with the forms of coaching that should be. (2) Supporting and inhibiting factors related to coaching factors (a) Facilities and infrastructure (b) social factors (c) factors of support from the School. Keywords: Extracurricular Coaching, Football.
\end{abstract}

Keywords: Extracurricular, Coaching

\section{INTRODUCTION}

The problem with this research is the low achievement of Semen Padang High School Football. Since 2018-2019, Football in Senior high school of Semen Padang has never been a winner anymore at the LPI level, moreover, there is a gap between the fact and the expectation where the expectation ofsenior high school of Semen Padang wants to be a winner in every match. Based on the background of the problem, the problem was formulated, namely how to develop extracurricular of Semen Padang High School with research questions as follows: What is the pattern of coaching students who take football extracurricular in Semen Padang High School.

Coaching is a business, action, and activity carried out efficiently and effectively to obtain better results. While coaching according to A.Mangunharja in Wandi (2013) " Coaching is an effort that is carried out efficiently and successfully to improve or obtain better results".

Many sports activities are supporting factors that influence to get achievements, such as physical condition, technique, no tick, and mentality (Soniawan, 2018 ). In soccer, besides having good physical, technical, tactic and mental conditions, good technical mastery is needed for the athlete, because without good technical mastery, an athlete cannot realize his achievements.

In sports coaching through schools, there are basically two kinds, namely extracurricular activities and extracurricular activities, both of which are as a means of effective activities. In relation to fostering sports performance, there are many factors that must be considered, including clear coaching objectives, systematic training programs, appropriate training materials and methods, and evaluations that can measure the success of Hidayat's coaching process (2015)

Ekstrakuricular is an educational activity outside the subject and counseling services to help the development of students in accordance with their needs, potential, talents, and interests through activities that are specifically organized if the education or educational staff who are capable and authorized in schools/madrasas are concerned in Mahputra and Vishnu (2019). Football is a branch of sport, as Sudarmono, Annas, and Hanani (2018) put forward. Football is a team game, each team consisting of eleven players, and one of them as a goalkeeper.

\section{RESEARCH METHODS}

This type of research is a qualitative study using descriptive methods, and the place of this research is in Semen Padang High School. While this research was conducted in June 2019. Informant in this research were teachers, coaches, and students that follow the football ekstracuriculer in Senior high school of Semen Padang. Data collection techniques used were observati on, interviews, and documentation. The analysis of the data was done qualitatively who expressed by Miles danHubergman (BasrowidanSuwandi, 2008: 209) 
which consists of data reduction, presentation of data dan making a conclusion

\section{RESULTS AND DISCUSSION}

\section{Image General About Research Focus}

The development of soccer in the Semen Padang High School is one of the extracurricular activities located in the social center of PT Semen Padang Indarung-Padang in West Sumatra Province.

Football branch extracurricular development is a further step in developing a competency-based curriculum that

\begin{tabular}{|c|l|l|}
\hline NO & \multicolumn{1}{|c|}{ Caretaker Name } & \multicolumn{1}{|c|}{ POSITION } \\
\hline 1 & Drs. Zaiful Anwar & Advisory \\
\hline 2 & $\begin{array}{l}1 . \quad \text { Drs. Junaidi } \\
2 . \quad \text { Drs. Dasril }\end{array}$ & $\begin{array}{l}\text { Builder / Director } \\
\text { Builder / Director }\end{array}$ \\
\hline 3 & $\begin{array}{l}\text { Dra. Yusrawati Dwi } \\
\text { Putri }\end{array}$ & Chief Coordinator \\
\hline 4 & Linda Sari, S.Pd & Deputy Coordinator \\
\hline 5 & Vita Memory, S.Pd & Treasurer \\
\hline 6 & $\begin{array}{l}\text { Siska Dwi Yani, } \\
\text { S.Pd Secretary }\end{array}$ & $\begin{array}{l}\text { Moethia Varina } \\
\text { Oemar, S.Pd Data processing }\end{array}$ \\
\hline 8 & April Chan, M.Pd & Field Person in Charge \\
\hline \multicolumn{3}{|l|}{ Extracurricular Trainer of Semen Padang }
\end{tabular}

\section{High School}

Based on the observations of researchers and interviews conducted by researchers, extracurricular trainers of Semen Padang High School numbered 2 people, Mr. Ryan Damara and Kevin Wilandi Syofnevil, S.Sc. But the active trainer for each activity is Mr. Kevin Wilandi Syofnevil, S.Sc.

3) Extracurricular Students in Semen Padang High School

From the observations and interviews of researchers in the field, the number of students participating in extracurricular activities is around 33. Researchers find the exact number because schools have complete data in the form of absences.

\section{4) Facilities and infrastructure}

From observations and information that researchers obtained, the place of researchers who became the center for football extracurricular training was at the social center of PT Semen Padang IndarungPadang precisely in the Cudak field of PT Semen Padang. For training facilities, the researchers looked at the time of observation to school the equipment available at the warehouse was not quite enough but there were cone and improvised balls. was pioneered in 2004 and KTSP 2006 which includes integrated attitude, knowledge and skills competencies. The purpose of extracurricular activities at Semen Padang High School is to foster a sense of confidence and pride as a student of Semen Padang High School, promoting the good name of the Igasar foundation and PT Semen Padang.
2. Research Findings
a) TemuanUmum
1) Management Structure

\section{b. Specific Findings \\ 1) Pattern of Extracurricular Coaching in Semen Padang High School}

Seeing the statement from the coach because there is a clear level of coaching patterns that exist in the extracurricular football of Semen Padang High School, while the instructor teacher puts forward the coaching conducted in the extracurricular football activities of Semen Padang High School involving BK to balance the extracurricular activities participated by the students with learning activities Factors

2) Extracurricular Inhibiting and Supporting

From interviews with several informants above, it can be seen that the supporting factors of the extracurricular activities at Semen Padang High School are the availability of facilities and infrastructure and competent trainers in their fields. While the inhibiting factors for extracurricular activities at Semen Padang High School are lack of competition and inadequate funding.

\section{Discussion}

1. The pattern of extracurricular soccer coaching at Semen Padang High School

Essaywith which researchers see and researchers compare it with answers that researchers gather that: guidance provided to learners not run in accordance with the development patterns that researchers propose that means coaching students taught still common.

2. Supporting and inhibiting factors for extracurricular soccer coaching at Semen Padang High School

\section{a) Supporting Factors}

Supporting actors in coaching students who take extracurricular football at Semen Padang High School are related to facilities and infrastructure. In addition, social factors are also established between the trainers of students between students and alumni who help in the training process.

\section{b) Obstacle Factor}

The inhibiting factor in coaching students who take part in the football extracurricular findings of the 
first researcher is about organizing in coaching activities.

\section{CONCLUSIONS AND SUGGESTIONS}

Based on the description of the results of research and discussion that has been done, the researcher can draw conclusions as follows:

1. The pattern of coaching given to students has not proceeded in accordance with the coaching pattern that the researchers propose meaning that the coaching of students taught is still general, besides that the media used are already good such as using cell phones, laptop, infocus, field, and ball but not all students who can understand the function of it all.

2. Supporting and inhibiting factors

a) Supporting factors in coaching students who take extracurricular football at Semen Padang High School are related to facilities and infrastructure. In addition, social factors are also established between the trainers of students between students and alumni who help in the training process. And supporting factors to achieve good coaching such as personality, physical condition, technical skills, tactical skills and the ability to think.

b) The inhibiting factor in coaching students who take part in the football extracurricular findings of the first researcher is about organizing in coaching activities. Researchers see that the organization is going well, but there are also obstacles in carrying out activities, such as the coach where the soccer extracurricular coach at Semen Padang High School is often not specified and also the facilities and infrastructure that are said to be complete in interviews with informants are not clearly seen by researchers.

\section{REFERENCES}

[1] Basrowi \& Kelvin. 2008. Understanding Qualitative Research, Jakarta: Rinika Cipta.

[2] Hidayat. 2015. Evaluation of the Persibas Bayuma Club Football Achievement Program. Journal of Sport Sciences and Fitness . No 2. pp. 10-15.

[3] Mahaputra, Anang \& Wisnu, Hari. 2019.

Identification of Causes of Low Student Interest in Sports Extracurricular Activities at SMAN 11 Surabaya. Journal of Sports and Health Education. No.12. P. 75-78

[4] Soniawan, V. Playing Method Has Influence on the Ability of Long Passing Football .

[5] Sudarsono, Annas \& Hanani. 2018. Football Extracurricular Coaching System in Bayumas Regency. JOURNAL OF INJURY. (Number 1 in 2018). P. 64-75

[6] Wandi, Sustiyo. 2013. Development of P restasi Karangturi High School Extracurricular Sports in Semarang. Journal of Physical Education, Sport, Health and Recreations . (Number 2 of 2013). P. 524-535. 